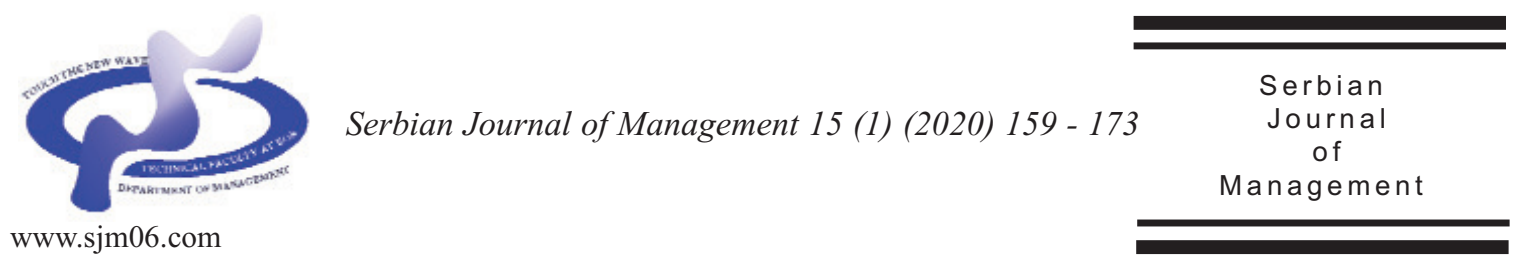

\title{
SOCIAL CAPITAL AS COMPETITIVE RESOURCE - A DRIVER TOWARDS SUSTAINED COMPETITIVE ADVANTAGE AMONG MANUFACTURING MSMES IN EMERGING MARKETS
}

\author{
Vidhya Vinayachandran* and Ambilysadanam Soman Ambily \\ Department of Commerce and Management, Amrita School of Arts and Sciences, \\ Kochi, Amrita Vishwa Vidyapeetham, India
}

(Received 17 September 2019; accepted 03 March 2020)

\begin{abstract}
The strength of an emerging economy are the Micro, Small and Medium Enterprises as they paramount the economy to a greater extent. Since, MSMEs plays a greater role in the creation of wealth in advanced countries, there shall be justification on the less contribution of the same in developing economy. India as a developing economy should foster their industrial productivity and manufacturing MSMEs have a major role. It is being argued that the micro and small firms are exposed to sickness to a larger extent due to resource scarcity (Mehta \& Rajan, 2017). The present study analyses social capital as a resource from structural social capital dimensions of MSMEs with respect to Government organizations and commercial banks for strengthening social capital of manufacturing MSMEs. The study is conducted based on 90 manufacturing MSMEs in Kerala.
\end{abstract}

Keywords: micro sector, small sector, medium sector, emerging economy, competitive resources, capabilities, social capital

\section{INTRODUCTION}

Indian Industrial sector are predominated by Micro, Small and Medium Enterprises and their competitiveness needs to be improved right from firm perspective, later to industry and finally at the country level.

While looking from the perspective of developed economies especially European
Union, OECD countries like United States, Australia, Canada and some Asian countries like China \& Taiwan, the larger concentration of small and medium enterprises realized the success for such economies.

In India, Micro, Small and Medium Enterprises play a pivotal role as they constitute around 95 per cent among overall

\footnotetext{
* Corresponding author: vidyapoornasree@gmail.com
}

DOI: $10.5937 /$ sjm15-23207 
industrial sector. The micro enterprises shares the highest percentage among total MSME sector, followed by small and medium enterprises (Annual report, Ministry of MSMEs, 2017).

Therefore the present study focuses on the Micro Small and Medium Enterprises based on the theory of resource based view.

\section{LITERATURE REVIEWS}

\subsection{Competitiveness and Indian Manufacturing MSMEs}

India's competitiveness lies largely on MSMEs, especially manufacturing. The survival of small firms depends on the resources possessed by the firm. Studies on resources are made extensively in relation to their composite nature, relationships of resources and performance (Green,1997). But less studies have focused on the nature of competitiveness of resources, which may positively contribute towards firm capabilities.

The disparities in the growth rates among Indian States of Uttarpradesh, Maharashtra, Gujarat and Kerala put emphasis on the problem of regional industrial efficiency of MSME and the present study focuses within the region of Kerala which is positioned lower among various States.

A wide range of literatures from the year 2000 to 2018 for identifying the concepts of competitiveness of Indian manufacturing sector, relationship between competitiveness and SMEs, competitive advantage, resource based view, capabilities are reviewed from the publishers of emerald, elsevier, indersicence, for getting clarity on the short term performance of the firms. The Competitiveness of MSMEs depends extensively on the development of capabilities which may lead to superior performance within small and medium enterprises (Singh, 2013).

\subsection{Resource based view}

The resource based view, though in discussion since 20 years, still is not extensively used in strategic management for generating sustained competitive advantage for firms (Barney, 1991; Carraresi et al., 2012). Resources includes physical, human, organisational, entrepreneurial, a unique combination of which generates sustained competitive advantage. Each firm within the same industry are of heterogenous in nature. Firms are a combination of productive resources which are essential for generating capabilites within the firm (Björn, 2004). Competitive resources are classified as physical capital resources, entrepreneurs' capital resources and social capital resources and the present study analyses the aspects of social capital as an important resource.

\subsection{Competitive Resources as a driver towards Sustained competitive advantage in emerging markets}

Indian Manufacturing MSMEs' resources and capabilities are analysed by the authors from theoretical perspective which highlights the importance of competitive resources. There are firms which perform badly in attractive industries while certain firms perform well in declining industries. Resource Based View emerged as a solution to such performance differences among firms.

Sustained competitive advantage is generated by firm's unique combination of resources (Wernerfelt, 1984; Barney, 1991; 
Conner \& Prahalad, 1996; Dollinger, 1999). Successful enterprise creation is usually the result of tangible and intangible resources, which represents the strength and weakness thereby leading to competitive advantage (Grant, 1991). Tangible resources constitute physical capital such as location, facilities, plant and equipments, where Indian small and medium enterprises lacks considerably.

From Figure 1, there are wide disparities among states in terms of GDP contribution. This can be due to different reasons. Industrialisation to flourish in India requires more acquisitions of land. There are also other issues such as labour, electricity, water etc. Land acquisitions were favourable in industry friendly states especially Maharashtra, Gujarat and Tamil Nadu and such forced actions created violence in less industry friendly states (Mukherji, 2009). Indian industry should focus more on creating transparency for ensuring clearances and licenses to foster the growth of manufacturing. All these postulate the need to focus on physical capital as competitive resource.
Entrepreneurs' capital has evolved recently as an important resource, which determines the firm's ability to generate better income options. The decisions relating to the investment in physical capital, social capital and human capital depends on entreprenueurs' capital (Ngatno et al., 2016). The variables selected for entrepreneur capital are age, education and experience which is determined to have a significant impact on firms survival from the model of Bates (1990). The small and medium firms' survival in India is greatly influenced by entrepreneurs' age, experience, education, caste and social community (Bates, 1990). These are called entrepreneurs' human capital.

The Human capital as intangible resource is the investment made through education and training which in turn leads to increased human productivity resulting in increased firm performance (Schultz, 1961).

Social capital viewed from the point of view of external relationship is the relationship maintained by the firm with the institutions and players outside for

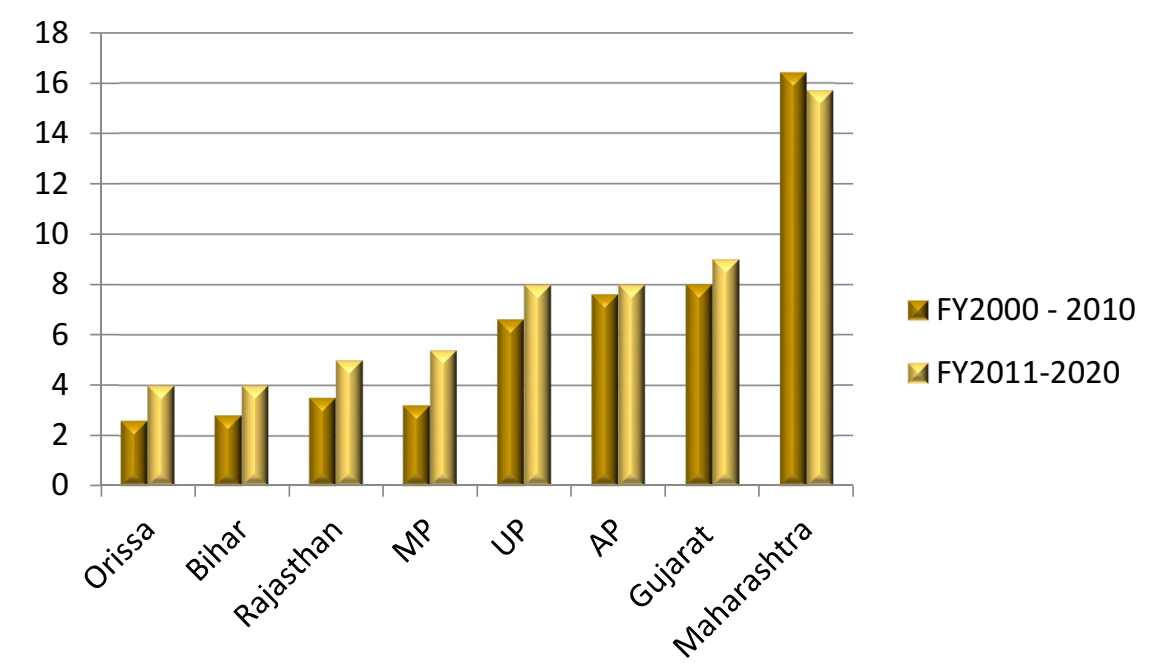

Source: MSME Annual report, Ministry of MSME 2017

Figure 1. Percentage distribution of MSME in top 8 States 
improving the performance of manufacturing MSMEs.

From Figure 2 it is depicted that the percentage contribution of institutional finance towards registered MSMEs is around 11.21 per cent, which is the major cause of self-financing by MSMEs (As per the fourth All India Census , 2006-2007).

It is noted that the timely and adequate support extended to manufacturing MSMEs are largely constrained by regulatory barriers. Relationship with customers helps small and medium enterprises to acquire new skills. Customer relationship ensures firm to be profitable, both in the short run and long run necessary to gain improved performance among manufacturing MSMEs in India.

This research, therefore examines to what extend variables explained with respect to Government and commercial banks strengthens social capital, which will foster improved performance among manufacturing MSMEs in India.

\subsection{Social capital as an important resource}

According to researchers, social capital has been viewed as an important resource for generation of information and knowledge through maintaining relationship either internally or externally. Micro, Small and Medium Enterprises need assistance and support from various government organizations and banks. Social capital mainly has three dimensions which includes structural, relational and cognitive (Nahapiet $\&$ Ghoshal, 1998). Structural social capital is the network under social system that enables to gain access among different players crucial for the survival of MSME. Acting within social system helps to improve knowledge and reduces transaction cost (Claridge, 2018). For the development and growth of MSME in developing economy, the role of Government is remarkable. There are different agencies controlled by Government to enhance the performance of MSME. For developing trust among Government organization timely support in the form of extending financial as well as promotional measures are crucial. Social capital is the network of relationships embedded within and external to the firm necessary for enhancing firm success. The existence of Micro, Small and Medium enterprises depends on the support extended by Government organizations as well as

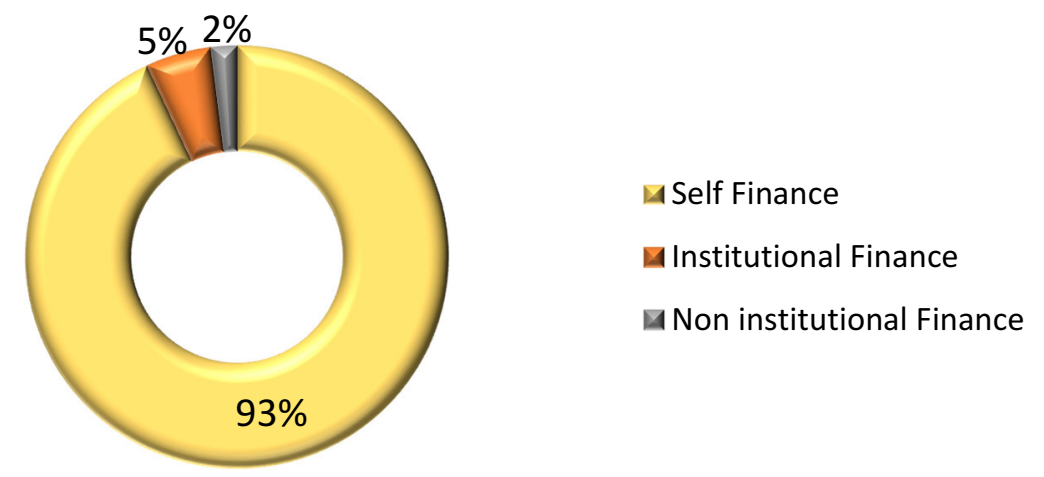

Source: Government of India (2011)

Figure 2. Distribution of finance among different sources 
commercial banks therefore considered as competitive resource.

Government organizations play a very important role in fostering entrepreneurship among emerging economies. Despite, Micro, Small and Medium Enterprises are handicapped as a result of several entry barriers in terms of stringent regulatory constraints, lack of financial and nonfinancial assistance etc. The regulatory constraints with respect to registration, acquiring licenses are still prevalent in developing countries (Simbi, 2016). In the case of many developing countries, as the Government plays a leading role in entrepreneurship development, there is a need to extend sufficient resources for the development of MSME. As per the GEM report (Reynolds, 2002), there is a lack of coordination among various Government organizations which hampers smooth administrative procedures with respect to their growth and survival. The Government's role in fostering social capital is commendable (De, 2001). Researchers studied different types of Government interventions in the form of financial assistance, provision of business information through arrangement of trade fairs and exhibitions encourage entrepreneurship (Verheul et al, 2001). The present section analyses the structural social capital of MSME with respect to Government organizations such as Directorate of Industries and Commerce, Kerala State Electricity Board, Kerala Small Industries Development Corporation, Kerala Industrial Infrastructure Development Corporation. With respect to the above discussions, the hypothesis framed is as follows:

Hypothesis 1 (H1): There is significant difference in Structured social capital with respect to Government among MSME.
Same as the case of commercial banks, are the major source of credit support for the survival of Micro, Small and Medium Enterprises. Commercial banks are the major source of credit support at the time of initial establishment of the enterprise. The inability of MSME in indulging in growth and developmental activities is due to inadequate finance. (Peter \& Inegbenebor, 2009). In many developing countries, banks consider SMEs as more profitable segment (de la Torre et al., 2010). Term loans and micro finance assistance from different banks such as public sector banks, private sector bank, within a period of 3 months is analyzed:

Hypothesis 2 (H2): There is significant difference in Structured social capital with respect to commercial banks among MSME.

Researchers pointed out that access to finance allows micro, small and medium enterprises to expand their business and acquire latest technology which facilitates efficient utilization o resources, expansion and diversification among small and medium enterprises (UNCTAD, 2001). Financial access enables all firms to develop and grow. Loans in the form of microfinance are insufficient for firms to grow and prosper. Access to finance enables Micro, Small and Medium Enterprises to indulge in different types of developmental activities such as expansion, innovation which ultimately improves the competitiveness of the firms (Beck \& Demirguc-Kunt, 2006). Also access to finance enables the firms to better utilize resources, by reducing cost (Shihadeh et al., 2019). Therefore the hypothesis framed is as follows:

Hypothesis 3 (H3): There is significant difference in developments made by MSMEs with respect to commercial banks

The present paper focuses on the structural dimensions which are necessary 
for strengthening social capital as competitive resource. Also it is essential for generating capabilities which is essential for superior firm performance and the resource of social capital is to be treated as competitive by entrepreneurs of micro, small and medium enterprises. Our findings are based on 90 firms in Kerala selected from different entrepreneurial associations.

\section{RESEARCH METHODOLOGY}

The study is purely descriptive and analytical in nature. The importance of social capital has been studied based on interview schedules based on established literatures. All constructs were selected based on conducting reliability test of Cronbach's alpha greater than 0.7 . Kerala is placed least among the top 10 States, based on the report of Entrepreneurs Memorandum Part II registered as per Ministry of MSME 201415. Therefore, the researcher focuses, on the district of Ernakulam, as Ernakulam is considered as the commercial hub of Kerala State. Apart from the same, Ernakulam is blessed with largest number of MSMEs within the State (Kerala State Planning Board, 2018). The sample of $90 \mathrm{MSME}$ firms was selected from a list provided by Directorate of Industries and Commerce, from engineering, food and plastic sectors. Engineering is selected as high growth sector among manufacturing sectors in India, followed by food and plastic which are categorised as modest growth sector (Mukherji, 2009).

\section{RESULTS AND DISCUSSION}

The results exhibited in Table 1 reveals that the regulatory construct AR1 has no significant impact on Micro, Small and Medium Enterprises as the standardised direct effect of this construct on Assistance obtained is 0.345 , which is less than the recommended value of 0.4 . Therefore this variable does not significantly contributes towards structural social capital. The registration of Micro, Small and Medium Enterprises is considered a tedious task because the registration with the concerned authority (Directorate of Industries and Commerce) takes a minimum of 1 year to clear all the procedures. In Kerala, for obtaining different licenses such as panchayat, pollution, power and labour, the entrepreneurs are faced with bureaucratic

Table 1. Showing regression co efficient of Structural social capital with respect to Government

\begin{tabular}{lccccc}
\hline Factors/Latent $\begin{array}{l}\text { Vependent Variable) } \\
\text { (Depiables }\end{array}$ & $\begin{array}{c}\text { Construct } \\
\text { (Independent } \\
\text { Variable) }\end{array}$ & $\begin{array}{c}\text { Regression } \\
\text { Coefficient }\end{array}$ & C.R. & P & $\begin{array}{c}\text { Variance } \\
\text { explained }\end{array}$ \\
\hline & AR1 & 0.345 & 3.356 & 0.001 & $11.9 \%$ \\
\cline { 2 - 6 } & AR2 & 0.439 & 4.393 & $<0.001$ & $19.3 \%$ \\
\cline { 2 - 6 } Structural Social Capital & AR3 & 0.331 & 3.208 & 0.002 & $10.9 \%$ \\
\cline { 2 - 6 } & AR4 & 0.483 & 4.915 & $<0.001$ & $23.4 \%$ \\
\cline { 2 - 6 } & AR5 & 0.194 & 1.833 & 0.07 & 3.7 \\
\cline { 2 - 6 } & AR6 & 0.679 & 7.716 & $<0.001$ & 46.1 \\
\hline
\end{tabular}

Source: Primary Data 
and regulatory barriers. Because of the same, the entrepreneurs lose enthusiasm for registration.

The results exhibited in Table 1 revealed that the variable AR2, with reference to support for obtaining power from Government has significant impact on Micro, Small and Medium Enterprises within one year as the standardised direct effect of this construct on Assistance obtained is 0.439 , which is more than the recommended value of 0.4 . At present the Kerala State Electricity Board of Kerala has become competent enough to supply timely and adequate power connections to MSME units, which underlines the strength of infrastructural developments of the State.

The results exhibited in Table 1 revealed that the technical support of Government within one year has no significant impact on social capital as the standardised direct effect of this construct on Assistance obtained is 0.331 , which is less than the recommended value of 0.4. There are different schemes provided by the Government of India under the platforms of SIDCO (Small Industries Development Corporation) and KINFRA (Kerala Industrial Infrastructure Development Corporation) which provides different raw material assistance as well as technology and machinery support to MSME units. But the entrepreneurs in Kerala are less aware about such assistance. At the same time, the Government is not spreading information and knowledge regarding the same. Therefore technical support obtained from Government is an important variable which strengthens social capital construct.

The results exhibited in Table 1 revealed that the variable AR4 has significant impact on social capital among Micro, Small and Medium Enterprises within one year as the standardised direct effect of this construct on
Assistance obtained is 0.483 , which is more than the recommended value of 0.4. Even though the Directorate of Industries and Commerce provide raw materials at subsidised cost, the entrepreneurs can avail the raw materials again at a reduced cost from their material suppliers. Therefore the variable does significantly impact on social capital construct of MSME units.

The results exhibited in Table 1 revealed that the variable AR5 in relation to obtaining quality standards has no significant impact on social capital construct Micro, Small and Medium Enterprises as the standardised direct effect of this construct on Assistance obtained is 0.194, which is less than the recommended value of 0.4. Quality standards are an important capability which is essential for the success of MSMEs. Therefore the stress on quality products should be more focused by MSME units, as quality is prime for consumers. The Government authorities should necessarily make rigorous quality checks periodically. Therefore periodic check in relation to quality standards should be treated as important variable which contribute social capital construct of MSMEs.

The results exhibited in Table 1 revealed that the variable AR6 has significant impact on Assistance obtained from the Government for Micro, Small and Medium Enterprises within one year as the standardised direct effect of this construct on Assistance obtained is 0.679 , which is more than the recommended value of 0.4. Even though the Directorate of Industries and Commerce offer machineries at concessional cost, the MSME units are more comfortable with their own machinery suppliers as there are less regulatory and political barriers relating to the same.

The results exhibited in Table 1 revealed 
that the variable AR7 has significant impact on structural social capital for Micro, Small and Medium Enterprises as the standardised direct effect of this construct is 0.949 , which is more than the recommended value of 0.4 . The MSME units are capable of availing subsidies during the inception stage irrespective of different sectors, yet the entrepreneurs does not have positive opinion in relation to the same, as it proves to be time consuming.

The results exhibited in Table 1 revealed that the variable AR8 has no significant impact on social capital construct for Micro, Small and Medium Enterprises as the standardised direct effect of this construct on Assistance obtained is 0.182 , which is less than the recommended value of 0.4 . So the hypothesis $\mathrm{H} 0 \mathrm{a} 8$ is rejected and concludes that AR8 (Participation in seminars and exhibitions) has significant effect on social capital for Micro, Small and Medium Enterprises. It is evident that seminars and exhibitions which are being organised at the National level, is limited to one (Annual report, Ministry of MSME 2017). But the seminars and exhibitions conducted by respective associations of engineering, food and plastic sectors are more than those conducted by Directorate of Industries and Commerce. Therefore, this variable participation in trade fairs and exhibitions) does not contributes significantly towards social capital construct of MSME.

Thus the hypothesis (H1) is partially accepted, since there is significant difference in structured social capital with respect to Government among MSME. Structured social capital with respect to Government is significantly differed for the variables AR2 (power supply within 1 year), AR4 (purchase of raw materials), AR6 (purchase of plant and machinery at subsidized cost), AR7 (availing subsidies). These differences occur as a result of lack of coordination among different departments/agencies with respect to Government (Reynolds, 2002). Also the studies conducted by different researchers puts forth the need for extending the start up assistance in the form of financial incentives as well as providing information with respect to national and international consumer preference through trade fairs and exhibitions for filling the knowledge gaps

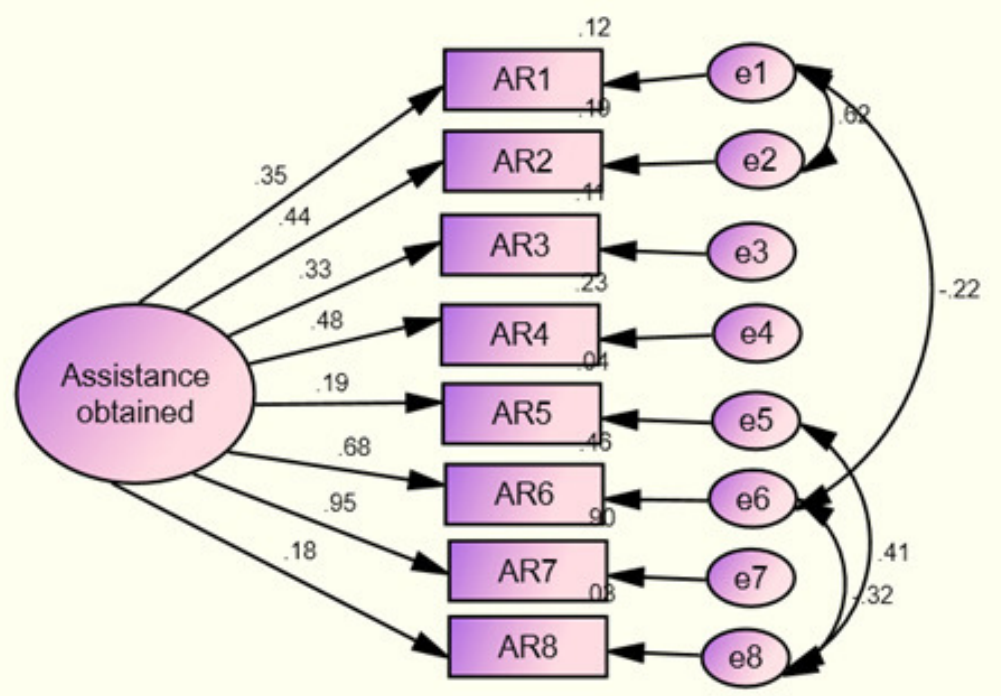

Figure 3. Confirmatory Factor Analysis 
Table 2. Showing the structured social capital with respect to commercial banks and MSMES

\begin{tabular}{|c|c|c|c|c|c|c|}
\hline \multirow{2}{*}{ Question } & & \multirow{2}{*}{ Parameters } & \multicolumn{3}{|c|}{ Type of business } & \multirow{2}{*}{ Total } \\
\hline & & & Micro & Small & Medium & \\
\hline \multirow{4}{*}{$\begin{array}{l}\text { Whether loans have been } \\
\text { availed in the preceding three } \\
\text { years' time period? }\end{array}$} & \multirow{2}{*}{ Yes } & Count & 13 & 23 & 19 & 55 \\
\hline & & Percentage & $40.6 \%$ & $65.7 \%$ & $82.6 \%$ & $61.1 \%$ \\
\hline & \multirow{2}{*}{ No } & Count & 19 & 12 & 4 & 35 \\
\hline & & Percentage & $59.4 \%$ & $34.3 \%$ & $17.4 \%$ & $38.9 \%$ \\
\hline \multirow{2}{*}{\multicolumn{2}{|c|}{ Total }} & Count & 32 & 35 & 23 & 90 \\
\hline & & Percentage & $100.0 \%$ & $100.0 \%$ & $100.0 \%$ & $100.0 \%$ \\
\hline
\end{tabular}

Source: Primary Data

among entrepreneurs (Verheul et al, 2001).This does not made any significant difference with respect to Structured social capital and MSME.

For the analysis initially an input model was developed by using AMOS-18 graphics. The rectangle represents observed factors, Ovals in drawn in the diagram represents unobserved variable. The curved double headed arrows represent correlations or covariances among the unobserved variables and the straight headed arrow represents the factor loadings of the observed variables. The small circles with arrows pointing from the circles to the observed variables represent errors/unique factors, which are also known as, squared multiple correlation of the standard error. This initial model is refined to reach the final model.

From the table no: 2 , it is clear that more than 60 per cent of MSME units have availed loans from commercial banks within 3 years' time period. This denotes that the traditional approach of banks in sanctioning loan have been changed and nowadays banks extent more support to Manufacturing MSMEs to a

Table 3. Chi-Square Tests

\begin{tabular}{lccc}
\hline & Value & df & p value \\
\hline Pearson Chi-Square & 10.436 & 2 & .005 \\
\hline significant & & & \\
\hline Source: Primary data & & &
\end{tabular}

greater extent.

From table no: 3 , it is clear that MSME units maintain positive relationship with banks and can be used as an important external institution for social capital. Therefore, there exist a positive relationship between commercial banks and MSMEs. Thus, the hypothesis (H2) is accepted as commercial banks are more supportive in sanctioning credit to Micro, Small and

Medium Enterprises. Thus as per the studies made by (de la Torre et al., 2010), commercial banks consider MSMEs as more viable form of profit generation.

For proving the objective, the following analysis has been carried out.

All the attributes loaded significantly on the latent constructs. The value of the fit indices indicates a reasonable fit of the measurement model with data. In table 5 we present the regression coefficient.

The results exhibited in Table 5 revealed that the regulatory construct D1 has significant impact on the developments made by the enterprises during the time period with the help of financial institutions as the standardised direct effect of this construct on Developments made is 0.541 , which is more than the recommended value of 0.4 . The interest rates from nationalised banks are comparatively lesser and this enables manufacturing MSMEs to approach financial institutions in a cordial way.

The results exhibited in Table 5 revealed 
Table 4. Model fit indices for developments made from commercial banks

\begin{tabular}{llllllllllll}
\hline & $\chi^{2}$ & DF & P & $\begin{array}{l}\text { Normed } \\
\chi^{2}\end{array}$ & GFI & AGFI & NFI & TLI & CFI & RMR & RMSEA \\
\hline $\begin{array}{l}\text { Developments } \\
\text { made }\end{array}$ & 13.316 & 11 & .273 & 1.211 & .961 & .900 & .927 & .972 & .986 & .109 & .049 \\
\hline
\end{tabular}

Source: Primary data

Table 5. The regression Coefficients -Developments made from commercial banks

\begin{tabular}{cccccc}
\hline $\begin{array}{c}\text { Factors/ } \\
\text { Latent } \\
\text { Variables } \\
\text { (Dependent } \\
\text { Variable) }\end{array}$ & $\begin{array}{c}\text { Construct } \\
\text { Independent } \\
\text { Variable) }\end{array}$ & $\begin{array}{c}\text { Regression } \\
\text { Coefficient }\end{array}$ & C.R. & P & $\begin{array}{c}\text { Variance } \\
\text { explained }\end{array}$ \\
\hline & D1 & 0.541 & 5.648 & $<0.001$ & $29.3 \%$ \\
\cline { 2 - 6 } & D2 & 0.555 & 5.835 & $<0.001$ & $30.8 \%$ \\
\cline { 2 - 6 } Developments \\
\cline { 2 - 6 } made & D3 & 1.033 & 19.218 & $<0.001$ & $106.6 \%$ \\
\cline { 2 - 6 } & D4 & 0.302 & 2.908 & 0.005 & $9.1 \%$ \\
\cline { 2 - 6 } & D5 & 0.799 & 10.221 & $<0.001$ & $63.9 \%$ \\
\hline
\end{tabular}

Source: Primary data

that the regulatory construct D2 has significant impact on the developments made by the enterprises during the time period with the help of financial institutions as the standardised direct effect of this construct on Developments made is 0.555 , which is more than the recommended value of 0.4 . . The manufacturing MSMEs, with the help of financial institutions are able purchase machinery of high quality, through which they are able to pursue their operations without any wastage, thus reducing the cost of operations.

The results exhibited in Table 5 revealed that the regulatory construct D3 has significant impact on the developments made by the enterprises during the time period with the help of financial institutions, as the standardised direct effect of this construct on Developments made is 1.033 , which is more than the recommended value of 0.4 . Therefore D3 (Increase in sales) has significant effect on developments made by the enterprises during the time period with the help of financial institutions.

The results exhibited in Table 5 reveals that the regulatory construct D4 has no significant impact on developments made by the enterprises during the time period with the help of financial institutions, as the standardised direct effect of this construct on developments made is 0.302 , which is less than the recommended value of 0.4 . Therefore D4 (Better social contacts) has no significant effect on developments made by the enterprises during the time period with the help of financial institutions. This is because, better social contacts especially in relation to customers and suppliers are very crucial for maintaining better relationship. But the fact is that, the loans obtained are used only for running and maintaining the day to day operations.

The results exhibited in Table 5 revealed that the regulatory construct D5 has significant impact on the developments made 
by the enterprises during the time period with the help of financial institutions as the standardised direct effect of this construct on Developments made is 0.799 , which is more than the recommended value of 0.4. So D5 (Maximum utilization of resources) has significant effect on developments made by the enterprises during the time period with the help of financial institutions. Physical resources like machinery, men, infrastructure etc. can be effectively utilised with the assistance, if judiciously employed.

The results exhibited in Table 4 reveals that the regulatory construct D6 has no significant impact on developments made by the enterprises during the time period with the help of financial institutions as the standardised direct effect of this construct on developments made is 0.377 , which is less than the recommended value of 0.4 . Hence, concludes that D6 (Diversification) has no significant effect on developments made by the enterprises during the time period with the help of financial institutions. Even with the support of financial institutions, the manufacturing MSMEs are struggling to survive their business in the long run. Hence, diversification of business is impossible.

The results exhibited in Table 5 reveals that the regulatory construct D7 has no significant impact on developments made by the enterprises during the time period with the help of financial institutions as the standardised direct effect of this construct on developments made is 0.314 , which is less than the recommended value of 0.4 . and hence D7 (Modernization) has no significant effect on developments made by the enterprises during the time period with the help of financial institutions.

Thus the hypothesis (H3) is partially accepted as there is significant difference in developments made with respect to commercial banks for the variables D1, D2, D3, and D5. Access to finance from commercial banks enables Micro, Small and Medium Enterprises to indulge in expanding their business through increased production by utilizing sophisticated technology, increased sales volume, as well as through better utilization of resources (Shihadeh et al., 2019; UNCTAD, 2001)

\section{FINDINGS OF THE STUDY}

The present study indicated the findings with respect to determinants of structured social capital. The results revealed that both the Government and commercial banks played very important role in strengthening the same. From the analysis, it is being inferred that the structural social capital with respect to Government is important for micro, small and medium enterprises has a significant impact with respect to the firm ,from the stage of inception. Structured social capital with respect to Government is significantly differed for the variables AR2 (power supply within 1 year), AR4 (purchase of raw materials), AR6 (purchase of plant and machinery at subsidized cost), AR7 (availing subsidies). From the stage of inception, the Government should be supportive as MSMEs are the pillars for national development. The MSME registration is a tedious task and it is not being sanctioned by the respective Government instantly. Even though technological support is offered from the Central Government, huge bureaucracy restrains the entrepreneurs from availing technological schemes.

The commercial banks have developed positive attitude with respect to MSME in terms of sanctioning loans. The hypothesis 
(H2) is accepted as commercial banks are more supportive in sanctioning credit to Micro, Small and Medium Enterprises. As per the studies made by (de la Torre et al., 2010), commercial banks consider MSMEs as more viable form of profit generation. The Micro and Small units should make efforts to make timely payment, which enhances the relation of micro and small units with them.

1. The Government as an external player plays a significant role for strengthening the structural social capital of Micro, Small and Medium Enterprises.

2. Even though there are tremendous initiatives from the Ministry of MSMEs in India, in relation to easy registration in the form of Udyog Aadhar, the older generation of MSMEs has no opinion for the adoption of the same by respective State Government.

3. Contrary from the industrial scenes of Tamil Nadu and Gujarat, the State of Kerala is not industry friendly. Therefore any schemes introduced at the Central level is very difficult to be implemented in the State. Ancillarisation is the most commonly found among small scale industries in Kerala, where such industries are promoted more by the Governments in the State of Tamil Nadu, Karnataka and Gujarat.

4. The Central Government should appoint respective officials from the Ministry of MSME at the Central level and have periodical checks in relation to the working of the units.

5. Even though, many entrepreneurs are the recipients of Entrepreneur Support Schemes, timely availability of the scheme is a crucial factor.

6. Government should focus on those units which are capital intensive, especially those in the engineering because there are larger concentrations of engineering units running at micro level.
7. The public sector undertakings in Kerala like Hindustan Machine Tools Limited, Appolo Tyres, Hindustan Insecticides Limited, Forest Industries of Travancore, Travancore Cochin Chemicals, Cominco Binani Zinc, Cochin Shipyard, Cochin Refineries, Hindustan Organic Chemicals, etc., should necessarily take orders completely from ancillary industries located in Kerala.

8. At present, the interest payments by MSMEs are made in a timely manner. Therefore, there is a positive change in the mind set of financial institutions in terms of providing loans.

\section{CONCLUSIONS AND POLICY IMPLICATIONS}

The study points out the importance of social capital as a competitive resource created from external relationship maintained with formal organization (Government), where interactive support and cooperation is very much vital for manufacturing MSMEs survival. The researches points out the limitations of Government of Kerala in fostering entrepreneurship through the medium of social capital construct. More initiatives should be focused for the enhancement of Manufacturing MSMEs in Kerala. The reason it stands least among top 10 States is because of lack of Government promotion by the state. But there is a change in the attitude of financial institutions to encourage industrial atmosphere and foster entrepreneurship in the State of Kerala. Development of capabilities extremely depends on the positive relationship maintained with the Government and Financial institutions. 


\title{
ДРУШТВЕНИ КАПИТАЛ КАО КОНКУРЕНТНИ РЕСУРС - УПРАВЉАЧ ДО ОДРЖАВЕНЕ КОНКУРЕНТНЕ ПРЕДНОСТИ МЕБУ ПРОИЗВОДНИМ ММСП-а НА ТРЖИШТИМА У РАЗВОЈУ
}

\author{
Vidhya Vinayachandran, A.S.Ambily
}

\section{Извод}

Снага економије у развоју су микро, мала и средња предузећа јер она у највећој мери дају предност економији. Будући да ММСП играју већу улогу у стварању богатства у напредним земљама, оправдање ће бити мање доприноса истих у привреди у развоју. Индија као економија у развоју требало би да подстиче своју индустријску продуктивност и да производна ММСП имају главну улогу. Тврди се да су микро и мале фирме изложене болестима у већој мери због недостатка ресурса (Мехта и Рајан, 2017). Ова студија анализира друштвени капитал као ресурс из димензија структурног друштвеног капитала ММСП у односу на владине организације и комерцијалне банке за јачање социјалног капитала од производних ММСП. Студија је спроведена на основу 90 производних ММСП у Керали.

Кључне речи: микро сектор, мали сектор, средњи сектор, економија у развоју, конкурентски ресурси, способности, друштвени капитал.

\section{References}

Barney, J. (1991). Firm Resources and Sustained Competitive Advantage. Journal of Management, 17 (1), 99-120.

Bates, T. (1990). Entrepreneur Human Capital Inputs and Small Business Longevity. The Review of Economics and Statistics, 72 (4), 551-559.

Beck, T., \& Demirguc-Kunt, A. (2006). Small and medium-size enterprises: Access to finance as a growth constraint. Journal of Banking \& Finance, 30 (11), 2931-2943.

'Björn, J. (2004). Exploring Outsourcing Decisions using the Resource-based view of the firm. In BIR 2004 - 3rd International Conference on Perspectives in Business Informatics Research (pp. 1-16). Jönköping: Lund University. Retrieved from https://portal.research.lu.se/portal/files/6017 616/1488424.pdf.

Carraresi, L., Mamaqi, X., Albisu, L. M., \& Banterle, A. (2012). Strategic Capabilities and Performance: An Application of Resource-Based View in Italian Food SMEs. Pp. 186-209 in U. Rickert \& G. Schiefer (Eds.), System Dynamics and Innovation in Food Networks, Boon, DE: Universität Bonn-ILB Press.

Claridge, T. (2018). Dimensions of Social Capital - structural, cognitive, and relational. Social Capital Research, 1-4. Retrieved from https://d1 fs2th61pidml.cloudfront.net/wpcontent/uploads/2018/01/Dimensions-ofSocial-Capital.pdf?x49412.

Conner, K.R., \& Prahalad, C.K. (1996). A Resource-Based Theory of the Firm: Knowledge Versus Opportunism. Organization Science, 7 (5), 477-501.

de la Torre, A., Martínez Pería, M.S., \& Schmukler, S.L. (2010). Bank involvement with SMEs: Beyond relationship lending. Journal of Banking \& Finance, 34 (9), 2280-2293.

De, D. (2001). 'Fostering Entrepreneurship in Europe.' Pp. 107-128 in 
Entrepreneurship policy for the Future. A. Lundstrom \& L. Stevenson, Stockholm, SE: Swedish Foundation for Small Business Research.

Dollinger, M. (1999). Entrepreneurship (2nd ed., pp. 1-562). U.S.A.: Prentice Hall. Retrieved from https://campus.globalnxt.edu.my/FileReposi tory/Community/3079/148440/doc/Textboo k.pdf.

Government of India (2011). Annual report of Ministry of Micro, Small and Medium Enterprises 2010-11. Ministry of Micro, Small and Medium Enterprises, New Delhi, India. Retrieved from http://msme.gov.in/MSME-AnnualReport2010-11-English.pdf.

Grant, R. (1991). The Resource-Based Theory of Competitive Advantage: Implications for Strategy Formulation. California Management Review, 33(3), 114135. doi: 10.2307/41166664.

Greene, P.G., Brush, C.G., \& Brown, T.E. (1997). Resources in Small Firms: An Exploratory Study. Journal of Small Business Strategy, 8 (2), 25-40.

Kerala State Planning Board. (2018). ECONOMIC REVIEW 2017 (pp. 1-412). Thiruvananthapuram: Government of Kerala. Retrieved from http://spb.kerala.gov.in/ER2017/web_e/inde x.php.

Mehta, Y., \& Rajan, A.J. (2017). Manufacturing Sectors in India: Outlook and Challenges. Procedia Engineering, 174, 90-104.

Ministry of MSME. (2017). Annual report 2017-18. Retrieved from Government of India website: (https://msme.gov.in/sites/default/files/Annu alrprt.pdf)

Mukherji, R. (2009). The State, Economic Growth, and Development in India. India
Review, 8(1), 81-106.

Nahapiet, J., \& Ghoshal, S. (1998). Social capital, intellectual capital, and the organizational advantage. Academy of Management Review, 23 (2), 242-266.

Ngatno, Apriatni, E.P., \& Widayanto (2016). Human Capital, Entrepreneurial Capital and SME's Performance of traditional herbal industries in Central Java, Indonesia: The Mediating Effect of Competitive Advantage. Archives of Business Research, 4 (4), 9-25.

Peter, E.O., \& Inegbenebor, A. (2009). Capacity of SMEs in Nigeria to Access Institutional Equity Finance. Research Journal of Business Management, 3 (1), 1-5. Reynolds, P., Bygrave, W., Autio, E., Cox, L., \& Hay, M. (2002). Global Entrepreneurship Monitor 2002 Executive Report (pp. 1-44). London: Ewing Marion Kauffman Foundation. Retrieved from http:/file://C:/Users/User/AppData/Local/P ackages/Microsoft.MicrosoftEdge_8wekyb3 d8bbwe/TempState/Downloads/1313076587 GEM_2002_Global_Report.pdf.

Schultz, T.W. (1971). Investment in human capital : the role of education and of research. London, UK: The Free Press.

Shihadeh, F., Naradda Gamage, S., \& Hannoon, A. (2019). The causal relationship between SME sustainability and banks' risk. Economic Research-Ekonomska Istraživanja, 32(1), 2743-2760. doi: 10.1080/1331677x.2019.1655465.

Simbi, R. (2004). National Economic Consultative Forum. Report on the Policy Implementation Workshop For SMEs 25-27 October 2004. (Masters thesis). University of Nairobi. Retrieved from http://erepository.uonbi.ac.ke/bitstream/hand le/11295/97142/Simbi\%20Raymond_Multiagent $\% 20$ Based $\% 20$ Risk $\% 20$ Management $\% 20$ Platform $\% 20$ for $\% 20$ Small $\% 20$ and $\% 20$ 


\section{$\mathrm{M}$}

enterprise $\% 20$ Businesses $\% 20$ in $\% 20$ Kenya.

pdf? sequence $=1 \&$ is Allowed $=y$

Singh, J. (2013). Analysis of Trends in the Manufacturing Growth in Last Five years (2006-07 to 2011-12) (pp. 1-59). New Delhi: Ministry of Commerce \& Industry.

UNCTAD. (2001). Improving the Competitiveness of SMEs in Developing Countries, 1-149. Retrieved from: https://unctad.org/en/Docs/itetebmisc3_en.p df

Verheul, I., Wennekers, S., Audretsch, D., \& Thurik, T. (2001). An Eclectic Theory of Entrepreneurship: Policies, Institutions and Culture (pp. 1-48). Amsterdam and Rotterdam: Tinbergen Institute. Retrieved from http://hdl.handle.net/10419/85867.

Wernerfelt, B. (1984). A resource-based view of the firm. Strategic Management Journal, 5 (2), 171-180. 